Copyright (C) 2021 The Author/s

This work is licensed under a CC-BY 3.0 License

Peer review method: Double-Blind

Accepted: August 16, 2021

Published: September 21, 2021

Review article

DOI: https://doi.org/10.47305/JLIA2137345t

\title{
RUSSIA AND COVID-19: RUSSIAN ADAPTIVE AUTHORITARIANISM DURING THE PANDEMIC
}

\author{
Aram Terzyan \\ Center for East European and Russian Studies, Eurasia Institutes - California, USA \\ ORCID iD: https://orcid.org/0000-0002-8439-3678 \\ a.terzyan@eurasiainstitutes.org
}

\begin{abstract}
This paper explores Russia's response to Covid-19, with a focus on its implications for political freedoms and human rights across the country. It investigates the relationship between the pandemic and reinforcing authoritarianism in Russia. This paper is an in-depth case analysis that uses policy analysis and process tracing to examine Russia's response to Covid-19 and its effects on Russian domestic politics. The study concludes that the Russian authorities have considerably abused Covid-19-related restrictive measures, not least through curtailing the freedom of assembly and expression. In doing so the Russian authorities have conveniently shielded themselves from mass protests amid constitutional amendments and upcoming legislative elections. Nevertheless, while the authoritarian practices that the Kremlin resorted to during the pandemic are not much different from those of other authoritarian regimes, they proved insufficient in curbing anti-regime dissent. This study inquires into the political repercussions of crisis management in authoritarian regimes and concludes that their authoritarian reactions lead to further crackdowns on civil liberties and political freedoms.
\end{abstract}

Keywords: Russia; Covid-19; Crisis Management; Constitutional Amendments; Human Rights; Political Freedoms; Repression

\section{INTRODUCTION}

Excessive and disproportionate use of emergency powers and restrictions on political freedoms have raised concerns that "Covid-19 is infecting democracy itself" (Maerz et al. 2020). Along with devastating public health systems, and causing lockdowns of nations, the Covid-19 pandemic has posed formidable challenges to human rights worldwide. A well-informed observer notes that with a gratuitous toll being inflicted on democracy, civil liberties, fundamental freedoms, healthcare ethics, and human dignity, this has the potential to unleash humanitarian crises no less devastating than Covid-19 in the long run (Thompson 2020). Thus, one of the biggest questions regarding the political implications of the pandemic involves explaining the extent to which governments have violated democratic standards in their response to Covid-19. 
Notably, Bieber (2020) identifies four main aspects that might be shaped by the pandemic. These include the rise of nationalism and authoritarianism, along with deglobalization and the politics of fear (Bieber 2020).

Russia has been heavily affected by the outbreak of the pandemic, with over $7,140,070$ cases reported so far (Worldometer 2021). A question arises as to how the pandemic has influenced the political landscape of Russia - notorious for authoritarian and illiberal practices. A quick look at international human rights watchdogs shows a considerable decline in political freedoms and human rights across the country during the pandemic. This picture has much to do with the 'fraudulent constitutional referendum' held in 2020 and the 'unjust imprisonment' and 'attempted assassination' of opposition leader Aleksei Navalny. The pandemic-induced extraordinary times allowed the Kremlin to abuse the restrictive measures, while tightening its grip on the Russian society on the eve of the parliamentary elections of September 2021.

Not surprisingly, while consolidating their authoritarian practices, not least through limiting the freedom of expression, the Russian authorities would invoke as justification the need to fight Covid-19. In effect, political freedoms have been further compromised along with the Russian authorities' attempts at marginalizing pro-Navalny opposition groups. This paper specifically explores the adaptation of Russian authoritarianism to the pandemic, with a focus on its implications for political freedoms and human rights across the country.

\section{CONSTITUTIONAL AMENDMENTS IN THE LIGHT OF COVID-19}

Even before the outbreak of the Covid-19, the Russian political landscape underwent some changes, driven by the Russian President's insatiable desire to further solidify his power. The dismissal of Prime Minister Medvedevin in mid-January 2020 was aptly regarded as a "necessity to ensure the president's freedom in 'renewing' Russia's political system and attempting to spur the return of real income growth" (Nations in Transit 2021). Medvedev's dismissal coincided with the president's address to the nation on the necessity for constitutional amendments. Initiated by Putin with his annual presidential speech (Presidential Address 2020), the 1993 Constitution underwent amendments and got tailored to President's long-term political goals.

In March 2020, the parliament approved a constitutional reform that removes the two consecutive term limits on Russia's presidency, thus allowing President Putin to remain in office after the end of his presidential term in 2024 (Teague 2020, 1). Following a postponement due to the Covid-19, an all-Russian vote took place from 25 June to 1 July 2020. The voters were asked to answer the following question: "Do you approve the amendments to the Constitution of the Russian Federation?". According to the official data provided by the Central Electoral Commission of the Russian Federation, 78 percent of the voters casting a valid vote answered 'Yes' and 22\% answered 'No', with 
a turnout of 68 percent (CEC of the RF). Pomeranz (2021) notes, that in the process a flawed but forward-looking document has been stripped of much of its liberal potential and instead been transformed into a more traditional top-down system of governance (Pomeranz 2021, 1). Constitutional amendments have not been limited to presidential term limits. Rather, they have introduced a new power vertical (the unified system of public power) with a stronger presidency, and a weaker judiciary, while further downgrading Russia's civil liberties (Pomeranz 2021, 1).

In March 2021, the Venice Commission adopted an opinion on Russia's constitutional amendments. While noting that constitutional amendments introduced several positive changes, it also underlined several flaws in the substance of the amendments and the procedure of its adoption. Concerning the substance of the amendments, the Commission concluded that they have disproportionately strengthened the position of the President and have done away with some of the checks and balances originally envisaged by the Constitution. As for the procedure of the adoption of the amendments, the Commission noted that the speed of the preparation of such wide-ranging amendments was inappropriate for the depth of the amendments considering their societal impact (Venice Commission 2021).

Arguably, the pandemic allowed the Kremlin to prevent protesters from taking the streets due to lockdown-related restrictions. According to OVD-Info - a local human rights observer, on March 12, at least 16 people were arrested in at least five cities across Russia for peacefully protesting or planning to attend a protest against the proposed constitutional amendments. Most of the protests were held as one-person pickets, which is the only form of spontaneous street protest permissible under Russian law (Amnesty International, 2020). The opposition 'No!' campaign had applied to hold the protest but the mayor's office refused, citing the need to prevent the spread of the virus that causes Covid-19 (HRW 2020). In response, the organizers reduced the expected number of attendees to below 5,000, but the city authorities still banned the rally. Meanwhile, other mass gatherings, and particularly those organized by the local authorities themselves, were not affected by the new restrictions and were allowed to take place (Amnesty International 2020). Thus, the restrictive measures were abused to suppress dissent amid constitutional amendments.

\section{POLITICAL FREEDOMS DURING THE PANDEMIC}

In terms of freedom of assembly, it is necessary to note that while there are certain reasonable restrictions on mass gatherings during a pandemic, it has not been uncommon for Russian authorities to misuse and abuse restrictions. This is consistent with the ways that the Kremlin has sought to silence dissident voices and exert unlimited control over the society while invoking as justification the need to fight the pandemic. 
In the light of the public health emergency, the United Nations Special Rapporteur on the rights to freedom of peaceful assembly and association stated that "states' responses to Covid-19 threat should not halt freedoms of assembly and association" and that while "restrictions based on public health concerns are justified (...) it is imperative the crisis not be used as a pretext to suppress rights in general or the rights to freedom of peaceful assembly (...) in particular" (UN HR Office of the High Commissioner 2020).

Russians' right to peaceful assembly is enshrined not only in the country's constitution, but also in Russia's OSCE commitments, the Universal Declaration of Human Rights, and its international obligations under the International Covenant on Civil and Political Rights. According to Human Rights Watch (2021), at least 83 governments worldwide have used pandemics to justify violating the exercise of free speech and peaceful assembly. Authorities have attacked, detained, prosecuted, and in some cases killed critics, broken up peaceful protests, closed media outlets, and enacted laws criminalizing speech that they claim threatens public health. Among the victims are primarily journalists, activists, healthcare workers, political opposition groups, and others who have criticized government responses to the coronavirus (HRW 2021a).

In March 2020, the Russian authorities resorted to taking restrictive measures with the view to preventing the spread of Covid-19. The authorities gradually banned all mass gatherings. Police would invariably interfere with single-person protests, which do not require approval, while quite often referring to the social distancing and mandatory mask regime even when protesters wore masks (HRW 2021b). In May 2020, the Parliament increased the penalties under article 212.1 that regulate public gatherings. The Investigative Committee used the updated code in July to file charges against Yulia Galiamina, a member of the Moscow city council and vocal critic of Putin, for participating in several protests. In December, a Moscow court sentenced Galiamina to a two-year suspended sentence for posting information on social media and taking part in a peaceful public assembly (Freedom in the World 2021). In response to massive arrests of more than 100 people in Moscow and Saint Petersburg against constitutional changes, CE Commissioner for Human Rights called on the Russian authorities "to overhaul legislation and practice governing freedom of assembly and expression, including in the context of the pandemic, to align them with European human rights standards" (Commissioner for Human Rights 2020). The Commissioner restated that the sanitary restrictions introduced to fight the Covid-19 pandemic cannot be used to unduly limit human rights and freedoms (Commissioner for Human Rights 2020). While other restrictions were gradually reduced through the summer of 2020 and the authorities permitted officially brokered mass outdoor festivals, peaceful protests remained mostly outlawed. Essentially, the mounting public discontent with the Kremlin has prompted the latter into adopting a strategy of all-out repression to keep its firm grip on power. 
Not surprisingly, civil society, independent media, and political opposition have all witnessed the shift in the repressive nature of the state in 2021 (Nations in Transit 2021). The alleged poisoning of the opposition leader Alexei Navalny in August 2020 and his arrest upon returning to Russia in January 2021 triggered large-scale protests amid Covid-19. This has sparked one of the largest anti-government protests since 2011. In a video address recorded at the police station, Navalny called on his supporters to take to the streets. Mass-protests started on 23 January after his team's call for coordinated protests and the release of the film Putin's Palace, i.e. a Russian documentary film made by jailed Kremlin critic Navalny alleging that Vladimir Putin is the ultimate owner of an opulent palace, something the president denies (Reuters 2021).

The Russian authorities stated that they would deny any requests from Navalny's supporters to hold protests because of the pandemic-related ban on public assemblies imposed in Moscow. Similar statements have been issued in several other cities across Russia, referring to pandemic restrictions or noncompliance with the minimum 10-day advance notification rule. The head of Navalny's Moscow team headquarters stated that there was no point in seeking official authorizations for protests because they would not be authorized. In response to Navalny's supporters' attempts at mobilizing protesters through social media, the Russian authorities launched a massive crackdown on social media activism. Namely, the prosecutor's general's office demanded that social media companies restrict access to "illegal information" online (HRW 2021c).

Anti-government protests, that continued in February and March, led to police violence and mass arrests. According to Amnesty International (2021), during the first three protests more than 11,000 people were arrested, an unprecedented number even in Russia where dissent is routinely silenced. More than 100 criminal cases have been opened against protesters. Most have been charged with violence against police officers, with 12 prominent activists facing charges on the grounds of "breaching Covid19 sanitary restrictions by calling for the protests" (Amnesty International 2021).

The protests reached their peak on April 21 due to Navalny's health deterioration in prison. According to Human Rights Watch (2021) "there was less police violence and brutality on 21 April compared with the January and February pro-Navalny protests, but the authorities' continued clampdown on freedom of assembly is wholly unjustified (...)" (HRW 2021d). The Russian authorities referred to restrictions imposed due to the Covid19 pandemic (Ria Novosti 2021). Meanwhile, restrictions did not prevent progovernment events from taking place, such as the anniversary of Crimea's occupation in Moscow (HRW 2021d).

Beyond this, on 9 June, a Moscow court ruled that Navalny's Anti-Corruption Foundation (FBK) and his nationwide network of political activists should be designated 'extremist'; a move that has been largely regarded as part of a Kremlin campaign to silence opposition on the eve of upcoming parliamentary elections (Financial Times 2021). The Court's decision came a few days after Putin signed into force a law that 
banned the members or supporters of 'extremist organizations' from participating in national elections (Financial Times 2021). The US State Department condemned the court's ruling, stating that "Russia has effectively criminalized one of the country's few remaining independent political movements" (The US State Department 2021).

Moreover, there was a reference to the fact that it was not uncommon for the Russian authorities to have labeled groups 'extremist' to stigmatize supporters and justify abuses against them. In 2017, the Jehovah's Witnesses were designated an 'extremist' organization, effectively criminalizing the exercise of their peaceful religious practices' (The US State Department 2021). Essentially, Russian authorities stop at nothing to marginalize pro-Navalny activists and prevent them from entering into the parliament.

Moreover, the Kremlin's crackdown on the governor of Khabarovsk Sergei Furgal is indicative of the frictions between the central and local governments. Governor Sergei Furgal, a member of the opposition Liberal Democratic Party was arrested on suspicion of his complicity in the murder of entrepreneur Aleksandr Smol'skiy along with two other business figures in 2005-2006. The arrest was widely seen as part of the Kremlin's plan to remove a governor with considerable local support and the potential to challenge Putin's party in the region (Nations in Transit 2021). In September 2018, Furgal won Khabarovsk gubernatorial election, beating the incumbent from the United Russia party. Meanwhile, Furgal's arrest provided a fertile ground for having him dismissed. The city's residents rallied in support of Furgal, demanding his release and the transfer of the investigation from the capital back to Khabarovsk. Moreover, they were joined by residents in other cities in the region (HRW 2020). During the protests, civil society faced mounting state repression coupled with pandemic-related restrictions. Nevertheless, the ability of local groups to sustain public pressure on officials - whether on matters of democratic governance or, more commonly, on local and municipal issues - was notable (Nations in Transit 2021).

As regards 'freedom of expression', it has been equally restricted on public health grounds. Despite the constitutional provisions on freedom of expression, vague laws on extremism grant the authorities a great deal of discretion to silence dissident voices, not least through controlling media narrative on politically sensitive issues. A handful of independent outlets, that are still operating, are mostly either online or were forced to move headquarters abroad (Freedom in the World 2021). Not surprisingly, the pandemic has adversely affected independent reporting, with media outlets finding themselves under constant pressure emanating from the Kremlin. The Russian authorities constricted freedom of speech by adopting a national law to stop the spread of fake news on Covid-19. On 1 April 2020, amendments to the so-called 'fake news' law, first passed in 2019, criminalized the dissemination of "knowingly false information about circumstances posing a threat to the lives and security of citizens and/or about the government's actions to protect the population" (Amnesty International 2020). 
Individuals face up to five years' imprisonment if the dissemination of information leads to bodily harm or death, with hefty fines for the media (Amnesty International 2021). On 22 April 2020, Russia's Supreme Court specified that the punishments also apply to people who not only use mass media and telecommunication networks but also speak at meetings, rallies, distribute leaflets and hang posters. Within three months, according to one estimate, authorities opened at least 170 administrative and 42 criminal cases for allegedly spreading false information online about Covid-19 (HRW 2021a). That said, the pandemic provided a convenient 'legal framework' to the Kremlin to further limit media freedoms and silence dissident voices.

\section{INTERNATIONAL RESPONSE TO THE 'AUTHORITARIAN PANDEMIC' IN RUSSIA}

The Kremlin's abuses of the pandemic-related restrictions have been largely condemned by the international community. The constitutional amendments have been regarded as "controversial" (Freedom in the World 2021) and "fraudulent" (Nations in Transit 2021) aimed at extending the rule of President Putin and establishing absolute control: "Russian authorities' repressive and desperate attempts to silence anyone who challenges Vladimir Putin's grip on power are an affront to the Russian people, who are demanding accountability for the corruption pervading the entire political system" (Nations in Transit 2021), said director of Europe and Eurasia programs at Freedom House.

Dozens of countries called on releasing Navalny and framed his imprisonment as unlawful (Reuters 2021). The G7 Foreign Ministers and the High Representative of the European Union issued a joint statement on the arrest of Navalny, where they expressed deep concern about the "detention of thousands of peaceful protesters and journalists" (EEAS 2021) and called upon Russia "to adhere to its national and international obligations and release those detained arbitrarily for exercising their right of peaceful assembly" (EEAS 2021). Moreover, Biden's administration has taken a harder stance towards President Putin than his predecessor Donald Trump. Sanctions have been imposed on seven senior Russian officials and 14 entities involved in chemical and biological production. Under the sanctions, the assets of the officials in the US were frozen (BBC 2021).

In a coordinated move, in March 2021, the European Council decided to impose restrictions on four Russian high-ranking officials (the head of Russia's investigative committee, the Prosecutor-general, the Head of the national guard, and the Head of the Federal Prison Service) responsible for serious human rights violations, including arbitrary detentions, suppression of dissent, etc. This became the first example of the EU imposing sanctions in the framework of the new EU Global Human Rights Sanctions Regime - established in December 2020 (Council of the EU 2021). The sanctions regime enables the EU to target those responsible for acts such as genocide, crimes against 
humanity, and other serious human rights violations or abuses. The restrictive measures consist of a travel ban and asset freeze (Council of the EU 2021).

Overall, while the Russian authorities have taken advantage of the pandemicrelated restrictions to smoothly carry out constitutional changes and suppress antigovernment dissent, mass pro-Navalny protests, along with those in support of Khabarovsk governor are testaments of resilience and growing strength of the Russian civil society. Not surprisingly, despite the pandemic, the repressive actions of the Russian authorities have been met with dissenting reactions, supported by the international community's condemnations of the Kremlin's abuses.

\section{CONCLUSION}

The pandemic-induced extraordinary times allowed the Kremlin to abuse the restrictive measures, while tightening its grip on the Russian society on the eve of the parliamentary elections of September 2021. The Russian authorities 'made the most' of the pandemic-related restrictions to smoothly carry out constitutional changes and suppress pro-Navalny protests.

In effect, the long list of human rights violations during the pandemic, includes brutal suppression of peaceful protests, arbitrary detentions, along the Kremlin's excessive crackdown on freedom of expression. Nevertheless, despite the pandemic, the repressive actions of the Russian authorities have been met with dissenting reactions, thus speaking to the growing maturity and resilience of the Russian civil society. Overall, while the authoritarian practices that the Kremlin resorted to during the pandemic are not much different from those of other authoritarian regimes, they were insufficient in curbing anti-regime dissent. Further research is essential to exploring the Kremlin's responses to the advancement of Russian civil society. 


\section{REFERENCES}

1. Amnesty International. 2020. Russian Federation: Authorities Suppress Criticism of the Proposed Constitutional Amendments. 13 March 2020. Accessed June 7, 2021.

https://www.amnesty.org/download/Documents/EUR4619832020ENGLISH.pdf

2. Amnesty International.2021. Russia: Human Rights Crisis Deepens as Navalny Supporters Arrested en Masse. 22 April 2021. Accessed June 18, 2021. https://www.amnesty.org/en/latest/news/2021/04/russia-human-rights-crisisdeepens-as-navalny-supporters-arrested-en-masse/

3. Amnesty International Report 2020/21.2021. Accessed June 14, 2021. https://www.amnesty.org/en/countries/europe-and-central-asia/russianfederation/report-russian-federation/

4. BBC. 2021. Alexei Navalny: the US Imposes Sanctions on Russia. Accessed June 28, 2021. https://www.bbc.com/news/world-us-canada-56255694

5. Bieber, F. 2020. Global nationalism in times of the COVID-19 pandemic. Nationalities Papers, pp. 1-13.

6. CEC of the Russian Federation. All-Russian vote on the approval of amendments to the Constitution of the Russian Federation. Accessed June 6, 2021. http://www.cikrf.ru/analog/constitution-voting/hod

7. Commissioner for Human Rights. 2020. Accessed June 6, 2021. https://www.coe.int/en/web/commissioner/-/commissioner-calls-on-russianauthorities-to-overhaul-legislation-and-practice-governing-freedom-ofassembly-and-of-expression

8. Council of the EU. 2021. Press Release, 2 March 2021. Global Human Rights Sanctions Regime: EU Sanctions Four People Responsible for Serious Human Rights Violations in Russia. Accessed June 6, 2021. https://www.consilium.europa.eu/en/press/press-releases/2021/03/02/globalhuman-rights-sanctions-regime-eu-sanctions-four-people-responsible-forserious-human-rights-violations-in-russia

9. EEAS. 2021. G7 Foreign Ministers' Statement on Arrest and Detention of Alexei Navalny. Accessed June 14, 2021. https://eeas.europa.eu/headquarters/headquarters-homepage/92098/g7foreign-ministers-statement-arrest-and-detention-alexei-navalny en

10. Financial Times. 2021. Russia Outlaws Alexei Navalny's Organizations as 'Extremist'. June 10, 2021. Accessed June 24, 2021. https://www.ft.com/content/82ff1707-fd44-43e8-887d-85d02a656e6b

11. Freedom in the World. 2021. Accessed June 18, 2021. https://freedomhouse.org/country/russia/freedom-world/2021 
12. HRW. 2020. Most Covid-19 Restrictions Lifted, but Moscow is not Open for Protest. Accessed June 6, 2021. https://www.hrw.org/news/2020/07/22/mostcovid-19-restrictions-lifted-moscow-not-open-protest

13. HRW. 2020. Russia: Far East Peaceful Protester Facing Prosecution. October 14, 2020. Accessed June 6, 2021. https://www.hrw.org/news/2020/10/14/russia-fareast-peaceful-protester-facing-prosecution

14. HRW. 2021a. COVID-19 Triggers Wave of Free Speech Abuse. February 11, 2021. Accessed June 6, 2021. https://www.hrw.org/node/377786/printable/print

15. HRW. 2021b. Russia: Events of 2020. Accessed June 6, 2021. https://www.hrw.org/world-report/2021/country-chapters/russia

16. HRW. 2021c. Russia: Crackdown Ahead of Pro-Navalny Protests. January 22, 2021. Accessed June 24, 2021. https://www.hrw.org/news/2021/01/22/russiacrackdown-ahead-pro-navalny-protests

17. HRW. 2021d. Russia: Arbitrary Detentions at Pro-Navalny Protests. 22 April 2021. Accessed June 6, 2021. https://www.hrw.org/news/2021/04/22/russia-arbitrarydetentions-pro-navalny-protests

18. Maerz, S. F., Lührmann, A., Lachapelle, J., \& Edgell, A. B. 2020. Worth the sacrifice? Illiberal and authoritarian practices during Covid-19. Illiberal and Authoritarian Practices during Covid-19 (September 2020). V-Dem Working Paper, 110.

19. Nations in Transit. 2021. Accessed June 7, 2021. https://freedomhouse.org/country/russia/nations-transit/2021

20. Nations in Transit. 2021. The Antidemocratic Turn. Accessed June 21, 2021. https://freedomhouse.org/sites/default/files/2021-04/NIT 2021 final 042321.pdf

21. Pomeranz, W. 2021. Putin's 2020 Constitutional Amendments: What Changed? What Remained the Same? Russian Politics, 6 (1), pp. 6-26.

22. Presidential Address to the Federal Assembly. 2020. January 15, 2020. Accessed June 6, 2021. http://en.kremlin.ru/events/president/news/62582

23. Reuters. 2021. Kremlin Foe Navalny's "Putin Palace" Film Pushes Past 100 Million

24. YouTube Views. January 29, 2021. Accessed June 28, 2021. https://www.reuters.com/article/us-russia-politics-navalny-film-idUSKBN29YOCD

25. Reuters. 2021. Western Countries Call on Russia at UN Rights Body to Release Navalny. Accessed June 14, 2021. https://www.reuters.com/article/us-russiapolitics-navalny-un-idUSKBN2B41EH

26. Ria Novosti. 2021. Accessed June 8, 2021. https://ria.ru/20210420/moskva1729091632.html

27. Teague, E. 2020. Russia's Constitutional Reform of 2020. Russian Politics, 5 (3), pp. 301-328.

28. The US State Department. 2021. The Designation of Navalny-Affiliated Organizations as "Extremist". June 9, 2021. Accessed June 21, 2021. 
https://ru.usembassy.gov/the-designation-of-navalny-affiliated-organizations-asextremist/

29. Thomson, S., and Ip, E. C. 2020. COVID-19 emergency measures and the impending authoritarian pandemic. Journal of Law and the Biosciences, 7(1), Isaa064.

30. Worldometer. 2021. Coronavirus cases: Russia, Accessed September 13, 2021. https://www.worldometers.info/coronavirus/country/russia/

31. Venice Commission. 2021. Interim Opinion on Constitutional Amendments and the Procedure for their Adoption. Strasbourg, 23 March 2021. Accessed June 8, 2021. https://www.venice.coe.int/webforms/documents/?pdf $=C D L-A D(2021) 005-$ $\underline{\mathrm{e}}$

32. UN HR Office of the High Commissioner. 2020. Accessed June 6, 2021. https://www.ohchr.org/EN/NewsEvents/Pages/DisplayNews.aspx?NewsID =25788 \&Lang $\mid \mathrm{D}=\mathrm{E}$ 